\title{
Analisis Kemampuan Pemecahan Masalah Matematis Peserta Didik Ditinjau dari Resiliensi Matematis dan Gender
}

\author{
Rizqy Ayu Nurfitri ${ }^{1}$, Hella Jusra ${ }^{2}$ \\ ${ }^{1,2}$ Program Studi Pendidikan Matematika, Fakultas Ilmu Pendidikan, Universitas Muhammadiyah Prof. DR. HAMKA, \\ J1. Tanah Merdeka No 20, Jakarta Timur, Indonesia \\ ayunur2009@gmail.com
}

\begin{abstract}
Mathematical problem-solving skill is one of the skills required for students to learn mathematics. The reality of the situation indicates that it is in a low category, as the negative attitude in mathematics appears when students experience learning difficulties. The purpose of this study is to describe the ability to solve a mathematical problem based on mathematics resilience and gender. A purposive sampling technique was used in this study. Six participants from the VII grade were selected based on the mathematics resilience category with a different gender. Descriptive qualitative research is a research type that uses non-testing instruments, math tests, and interviews. This study used the data analysis model Miles and Huberman. The results showed that both genders with high resilience do not simply give up and satisfy the four indicators of Polya. However, female students are better than male students. In the meantime, only three Polya indicators have been met in participants classified as moderate resilience, but they have been unable to implement plans as they have failed to address problems. Male students, however, were better than female students, and when they were experiencing's problem both did not give up. Those who have low resilience have not been able to achieve the four indicators and they are easily relinquished when facing difficulties, but female students are better than male students.
\end{abstract}

Keywords: Mathematical problem solving's ability, Mathematics resiliences, Gender

\begin{abstract}
Abstrak
Kemampuan pemecahan masalah matematis adalah kebutuhan yang wajib dimiliki peserta didik. Faktanya kemampuan yang dimiliki termasuk kategori rendah karena muncul sikap negatif pada matematika saat menghadapi kesulitan. Mendeskripikan kemampuan pemecahan masalah matematis peserta didik ditinjau dari resiliensi matematis dan gender merupakan tujuan penelitian. Peneltian ini menggunakan teknik purposive sampling dengan 6 subjek penelitian kelas VII berdasarkan 3 kategori resiliensi matematis dengan dua peserta didik dari gender berbeda. Penelitian kualitatif deskriptif adalah jenis penelitian yang digunakan dengan menggunakan instrumen non tes, tes kemampuan matematis, dan wawancara. Penelitian ini menggunakan analisis data model Miles dan Huberman dengan hasil kedua subjek resiliensi tinggi tidak mudah menyerah saat mengalami kesulitan dan mampu memenuhi keempat indikator Polya namun perempuan lebih baik dari laki-laki, sedangkan subjek yang memiliki resiliensi sedang hanya mampu memenuhi tiga indikator Polya , subjek kurang mampu melaksanakan rencana karena kurang teliti dalam menyelesaikan masalah, namun subjek laki-laki lebih baik dari perempuan dan kedua subjek tidak menyerah saat mengalami kesulitan. Kedua subjek yang memiliki resiliensi rendah mudah menyerah saat mengalami kesulitan dan belum mampu memenuhi keempat indikator, namun perempuan lebih baik dari laki-laki.
\end{abstract}

Kata kunci: Kemampuan Pemecahan Masalah Matematis, Resiliensi Matematis, Gender

Copyright (c) 2021 Rizqy Ayu Nurfitri, Hella Jusra

$\bowtie$ Corresponding author: Hella Jusra

Email Address: hella.jusra@uhamka.ac.id (Jl. Tanah Merdeka No 20, Jakarta Timur, Indonesia)

Received 21 June 2021, Accepted 02 July 2021, Published 12 Juli 2021

\section{PENDAHULUAN}

Pendidikan adalah usaha sadar yang direncanakan secara sistematis untuk menciptakan lingkungan belajar dimana peserta didik berperan aktif untuk meningkatkan kemampuan yang ada di dalam dirinya (UU RI No.20 2003). Melalui proses pembelajaran yang aktif dapat menjadi sarana untuk mencerdaskan generasi bangsa. Negara yang berhasil mencerdaskan peserta didik terlihat dari kemampuan yang dimiliki untuk memecahkan masalah. Salah satu persyaratan dalam pendidikan di era ke-21 adalah keterampilan pemecahan masalah yang dianggap sebagai kebutuhan (Ince, 2018). Berdasarkan data Programme for 
International Student Assesment (PISA) yang dinobatkan oleh Organization for Economic Co-operation and Development (OECD) (OECD, 2019) pada PISA 2018 terdiri dari 76 negara memiliki skor rata-rata yaitu 489, skor Indonesia 379 pada urutan ke 71. Fakta tersebut mengindikasikan Indonesia termasuk rendah dalam pemecahan masalah dari negara lain artinya hal tersebut membutuhkan perhatian khusus untuk memperbaikinya.

Pemecahan masalah adalah sebuah sarana untuk peserta didik dalam mencerna masalah, merencanakan strategi, dan menyelesaikan masalah dengan menggunakan strategi dan metode secara sistematis. Menurut Rahmatiya \& Miatun (2020) pemecahan masalah matematis lebih menegaskan pada pemilihan strategi dan penggunaan prosedur yang dapat dibuktikan secara sistematis. Peneliti menganalisis menggunakan kerangka berpikir Polya dengan 4 langkah pemecahan masalah yaitu memahami masalah (understanding the problem), membuat rencana (make a plan), melaksanakan rencana (carrying out the plan), dan memeriksa kembali (looking back) (Polya, 1985).

Kemampuan pemecahan masalah matematis adalah keterampilan yang harus dikuasai untuk menumbuhkan minat matematika, keingintahuan, dan yakin pada kemampuan yang ada pada dirinya. Terdapat beberapa faktor akibat rendahnya kemampuan pemecahan masalah matematis seperti peserta didik tidak menyukai matematika sedangkan matematika termasuk pelajaran yang bersifat wajib untuk dikuasai (Davita \& Pujiastuti, 2020). Matematika adalah pelajaran yang kurang diminati karena bersifat abstrak dan terlalu banyak rumus yang harus dihafalkan, hal tersebut membuat peserta didik memiliki sikap negatif pada saat proses pembelajaran matematika (Winarso, 2017). Sikap negatif disebabkan oleh kesulitan dan hambatan yang dialami peserta didik saat proses pembelajaran matematika sehingga memberikan pengalaman buruk kepada peserta didik (Hutauruk \& Priatna, 2017). Untuk mengatasi sikap negatif peserta didik harus memiliki sikap pantang menyerah, percaya diri dan tekun yang disebut resiliensi matematis.

Resiliensi matematis adalah sikap peserta didik dalam menghadapi kesulitan saat pembelajaran matematika seperti sikap tekun, mau bekerja keras, dan gigih (Hafiz et al., 2017). Adapun indikator resiliensi yang digunakan dalam penelitian ini terdapat 4 faktor resiliensi matematis yaitu nilai, perjuangan, perkembangan, dan ketahanan (Megan et al., 2013). Hasil penelitian yang di lakukan oleh Rahmatiya menunjukkan peserta didik dengan kategori baik dalam kemampuan pemecahan masalah memiliki resiliensi tinggi, dan peserta didik dengan kategori kurang mampu memiliki resilieni matematis sedang (Rahmatiya \& Miatun, 2020). Namun penelitian yang dilakukan Rahmatiya dan Miatun terbatas pada kategori resiliensi tinggi dan sedang tanpa adanya subjek resiliensi rendah, perlu diadakan analisis kemampuan pemecahan masalah matematis dengan mempertimbangkan 3 kategori resiliensi, yaitu tinggi, sedang, dan rendah dengan memperhatikan gender di masing-masing kategorinya. Hasil penelitia Buranda \& Bernard, (2019) prestasi perempuan lebih rendah dari laki-laki dalam memecahkan masalah. Dari beberapa hasil penelitian tersebut, penelitian yang dilakukan memberikan gambaran tentang kemampuan pemecahan masalah matematis dengan melihat 3 kategori resiliensi dan dari segi gender yang merupakan tujuan dari penelitian ini. 


\section{METODE}

Penelitian kualitatif dengan pendekatan deskriptif merupakan jenis penelitian yang digunakan dengan tujuan menjelaskan kemampuan yang dimiliki subjek pada pemecahan masalah dengan mempertimbangkan resiliensi matematis dan gender. Pemilihan subjek dengan teknik purposive sampling yang memenuhi kriteria berdasarkan kategori terdapat 6 subjek penelitian kelas VII dengan 2 subjek resiliensi tinggi, 2 subjek resiliensi sedang, dan 2 subjek resiliensi rendah dengan gender yang berbeda pada setiap kategori. Analisis model Rasch digunakan untuk menentukan kategori resiliensi matematis tinggi, sedang, dan rendah. Selanjutnya, hasil tes yang sudah dikerjakan akan dianalisis sesuai dengan indikator kemampuan pemecahan masalah matematis menurut Polya dan dilanjutkan dengan wawancara kepada subjek yang terpilih mengenai jawaban dari tes matematika untuk mengkonfirmasi proses penyelesaiannya.

Penelitian ini mengumpulkan data dengan menggunakan instrumen non tes angket resiliensi matematis yang terdiri dari 36 pernyataan dengan mengadopsi instrumen dari Development and Validation of the Mathematical Resilience Scale (Kooken et al., 2016), instrumen yang digunakan memakai skala likert pada setiap butir pernyataan yang terdiri dari 4 pilihan skala. Sedangkan instrumen tes yang digunakan berjumlah 8 butir soal dengan indikator Polya: (1)memahami masalah, (2)membuat rencana, (3)melaksanakan rencana, dan (4)memeriksa kembali (Polya, 1985). Teknik wawancara terstruktur yang digunakan dalam penelitian namun pertanyaan dapat berubah sesuai jawaban dari peserta didik. Triangulasi sumber untuk mengumpulkan data dari enam subjek penelitian dengan proses pengumpulan informasi yang sama dan triangulasi teknik untuk memeriksa kredibilitas informasi dengan melihat data di subjek yang sama namun menggunakan cara yang berbeda adalah teknik menguji keabsahan data yang digunakan. Penelitian ini menggunkan analisis data model Miles dan Huberman yang pertama adalah reduksi data kemudian dilanjut dengan penyajian data dan terakhir penarikan kesimpulan (Rijali, 2019).

\section{HASIL DAN DISKUSI}

Angket resiliensi matematis diberikan kepada peserta didik kelas VII. Analisis model rasch digunakan untuk menentukan kategori resiliensi matematis tinggi, sedang, dan rendah yang menghasilkan output seperti dapat dilihat di gambar 1. Gambar 1 menunjukkan 218 peserta didik dengan 15 laki-laki dan 25 perempuan termasuk resiliensi matematis tinggi, 67 laki-laki dan 89 perempuan termasuk resiliensi sedang, sedangkan 12 laki-laki dan 10 perempuan termasuk resiliensi rendah. Selanjutnya dipilih 6 subjek yaitu 026L (RTL), 117P (RTP), 122L (RSL), 167P (RSP), 186L (RRL), dan 148P (RRP). Enam subjek penelitian dikodekan dengan RTL yaitu Resiliensi Tinggi Laki-laki, RTP yaitu Resiliensi Tinggi Perempuan, RSL yaitu Resiliensi Sedang Laki-laki, RSP yaitu Resiliensi Sedang Perempuan, RRL yaitu Resiliensi Rendah Laki-laki, dan RRP yaitu Resiliensi Rendah Perempuan. 


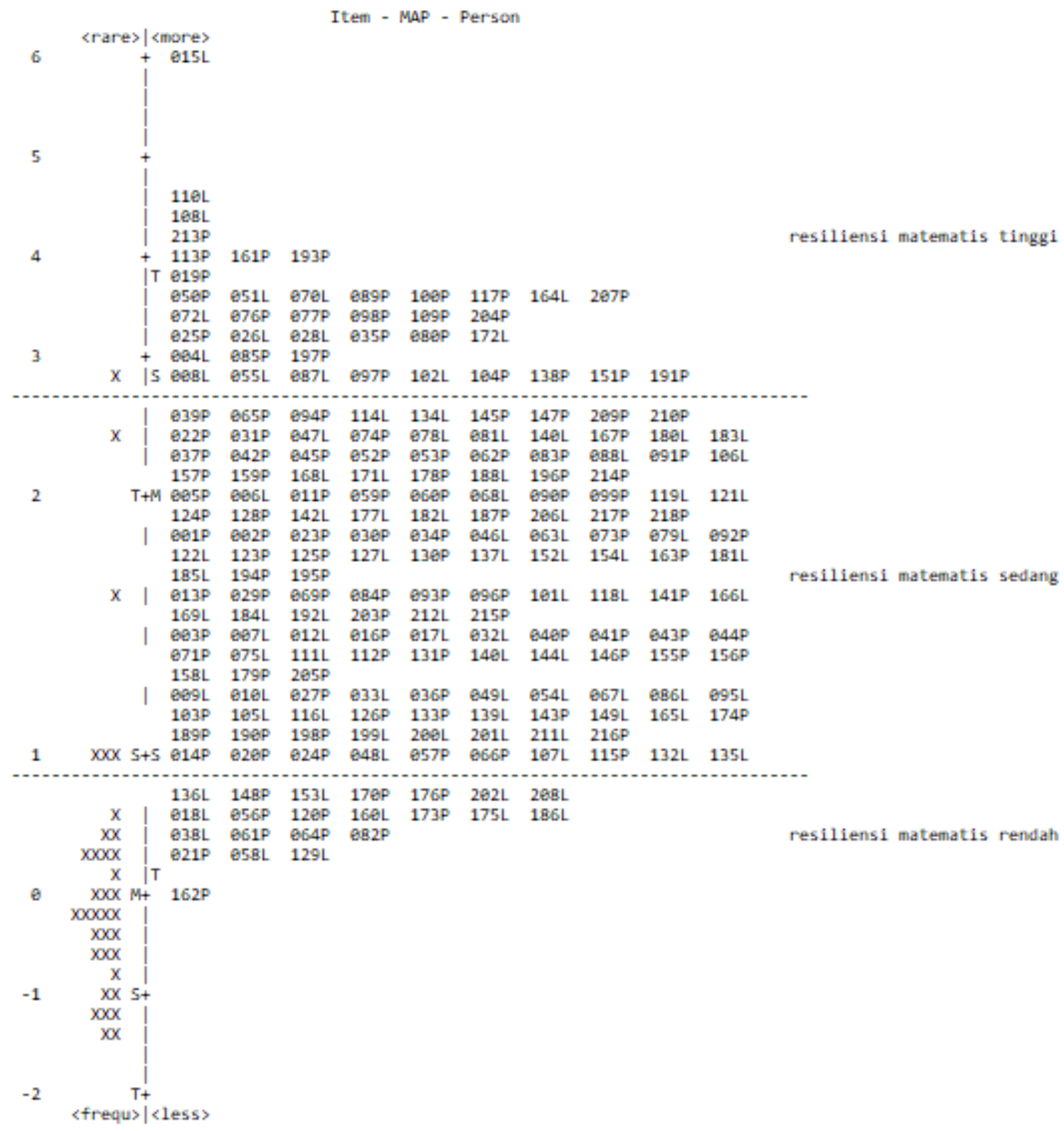

Gambar 1. Peta Distribusi Person-Item Resiliensi Matematis Peserta Didik

Berikut adalah analisis Jawaban Tes Kemampuan Pemecahan Masalah Matematis (JTKPMM) subjek yang terpilih dari 3 kategori resiliensi matematis pada soal nomor 1.

\section{Resiliensi Matematis Tinggi}

a. Memahami masalah

Pada gambar 2 dan 3 berikut dapat diketahui bahwa subjek RTL dan RTP sudah mampu memahami masalah, pernyataan tersebut diperkuat dengan hasil wawancara. Dimana RTP menuliskan yang diketahui dan ditanyakan pada soal dengan lengkap sedangkan RTL tidak menuliskannya.

b. Membuat rencana

Berdasarkan hasil JTKPMM menunjukkan subjek RTL dan RTP sudah mampu membuat rencana. Pada langkah ini subjek RTL dan RTP dapat menggunakan informasi yang ada untuk merencanakan strategi. 


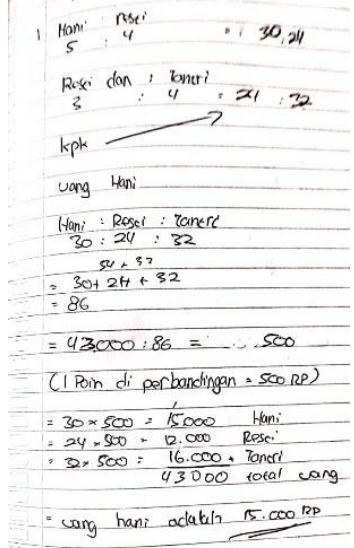

Gambar 2. hasil JTKPMM subjek RTL

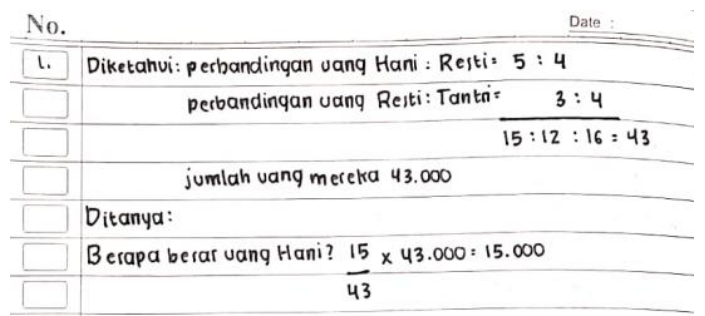

Gambar 3. hasil JTKPMM subjek RTP

c. Melaksanakan rencana

Dari gambar diatas dapat diketahui bahwa subjek RTL dan subjek RTP sudah mampu melaksanakan rencananya. RTL dan RTP mampu melaksanakan strategi penyelesaian sesuai dengan rencananya. Dimana subjek RTL menjawab soal dengan menggunakan cara yang berbeda dengan yang lainnya yaitu subjek RTL menyelesaikan permasalahan dengan menggunakan KPK untuk mencari perbandingan uang Hani, Resti, dan Tantri. Kemudian subjek RTL mencari besar 1 poin di dalam perbandingan dan di dapat 1 poin sebesar Rp500,00, selanjutnya subjek RTL mencari masing-masing uang Hani, Resti, dan Tantri. Subjek RTP melakukan proses penyelesaian dengan menyamakan perbandingan uang resti dilanjut dengan mencari jumlah dari perbandingan uang Hani, Resti dan Tantri untuk mencari besar uang Hani.

d. Memeriksa kembali

Subjek RTL dan RTP dapat melakukan langkah ini dengan baik, dimana kedua subjek sudah memereriksa kembali jawabannya dengan melakukan pemeriksaan pada proses perhitungannya dan dapat menyebutkan kesimpulan secara tepat.

$\mathrm{R} \quad$ : Informasi apa saja yang diketahui? $\mathrm{R} \quad$ : Informasi apa saja yang diketahui?

RTL : hani mempunyai perbandingan RTP : perbandingan uang hani : resti $=5: 4$ dengan resti 5:4 dan resti dan tantri 3:4 lalu uang yang mereka miliki Perbandingan uang resti dengan tantri $=3$ : adalah Rp43.000 4

$\mathrm{R} \quad$ : Lalu apa yang ditanya? Jumlah uang mereka adalah Rp43.000

RTL : maka tentukan besar uang Hani $\mathrm{R} \quad$ : Lalu apa yang ditanya?

$\mathrm{R} \quad$ : apa kesimpulan dari jawaban kamu?

RTP : besar uang hani

RTL : jadi uang Hani adalah Rp15.000

$\mathrm{R} \quad$ : jawbannya diperiksa lagi ga?

$\mathrm{R}$ : jawaban kamu diperiksa ulang

RTP : periksa saya itung ulang engga? 
RTL : udah liat lagi hitungannya.

\section{Resiliensi Matematis Sedang}

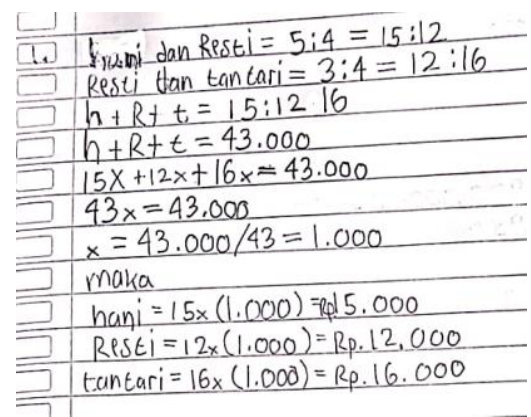

Gambar 4. hasil JTKPMM subjek RSL
RTP : jadi uang hani Rp15.000

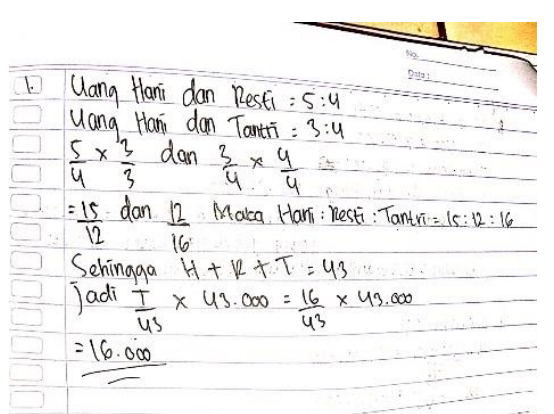

Gambar 5. hasil JTKPMM subjek RSP

a. Memahami masalah

Dari gambar diatas dapat diketahui bahwa subjek RSL sudah mampu memahami masalah, pernyataan tersebut diperkuat dengan hasil wawancara. Sedangkan subjek RSP mampu memenuhi indikator ini namun RSP keliru dalam membaca unsur yang ditanyakan.

b. Membuat rencana

RSL dan RSP mampu membuat rencana dimana kedua subjek dapat menggunakan informasi yang ada untuk merencanakan strategi yang digunakan.

c. Melaksanakan rencana

Dari gambar diatas dapat diketahui bahwa subjek RSL mampu melaksanakan rencananya sesuai dengan strategi penyelesaian yaitu dengan menyamakan perbandingan uang resti dilanjut dengan mencari nilai x untuk mencari besar uang Hani, Resti dan Tantri untuk mencari besar uang Hani, sedangkan subjek RSP menyamakan pembilang dan penyebut pada perbandingan tersebut dilanjut mencari jumlah perbandingan mereka bertiga dan mencari jumlah uang tantri.

d. Memeriksa kembali

Subjek RSL mampu memeriksa kembali jawabannya dengan melihat kembali proses perhitungannya sedangkan subjek RSP tidak memeriksa kembali jawabannya.

$\mathrm{R} \quad$ : Informasi apa saja yang diketahui? $\mathrm{R} \quad$ : Informasi apa saja yang diketahui?

RSL : Perbandingan Uang Hani dan Uang RSP : Uang hani dan resti $=5: 4$

Resti $=5: 4$

Uang hani dan tantri $=3: 4$

Uang Resti dan Uang tantari $=3: 4$

Jumlah uang mereka Rp43.000

$\mathrm{R} \quad$ : Lalu apa yang ditanya?

$\mathrm{R} \quad$ : Lalu apa yang ditanya?

RSL : tentukan besar uang hani

RSP : Uang tantri 


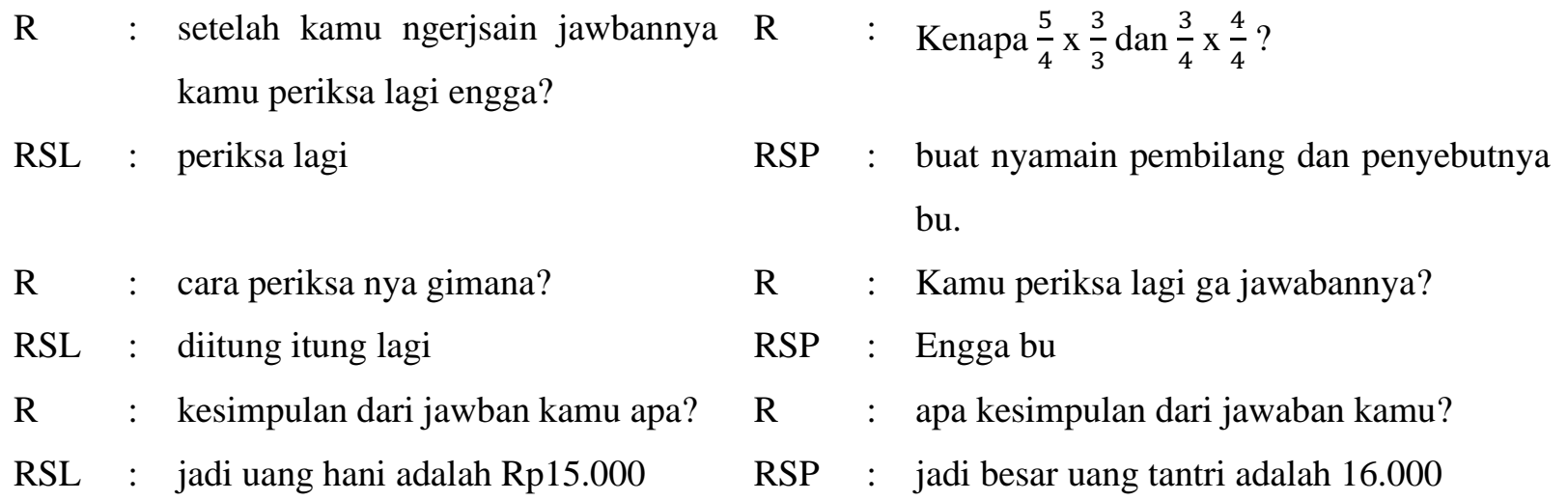

\section{Resiliensi Matematis Rendah}

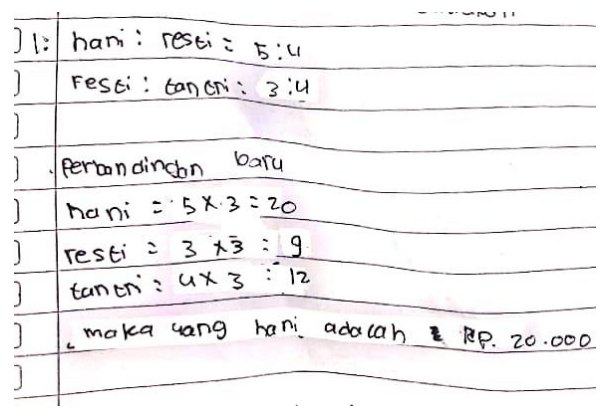

Gambar 6. Hasil JTKPMM Subjek RRL

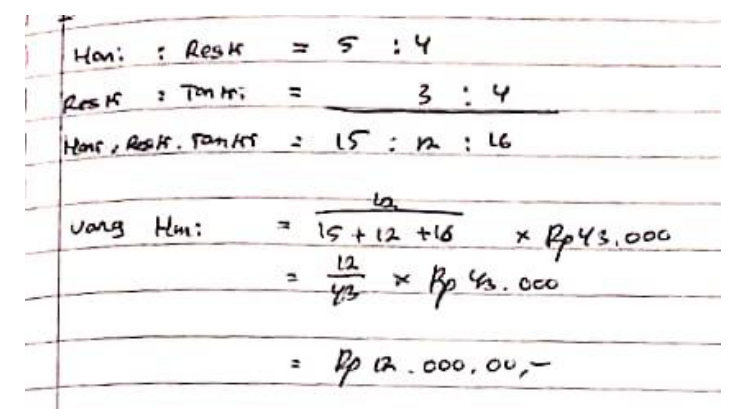

Gambar 7. Hasil JTKPMM Subjek RRP

a. Memahami masalah

Dari gambar diatas dapat diketahui bahwa subjek RRL dan RRP sudah mampu memahami masalah, pernyataan tersebut diperkuat dengan hasil wawancara. Namun kedua subjek tidak menuliskan yang diketahui dan tidak menulis yang ditanyakan.

b. Membuat rencana

RRL tidak mampu menggunakan informasi yang ada untuk merencanakan strategi yang digunakan. sedangkan subjek RRP sudah mampu merencanakan strategi yang akan digunakan.

c. Melaksanakan rencana

Dari gambar diatas dapat diketahui bahwa subjek RRL kurang mampu melaksanakan rencana karena RRL salah dalam menentukan strategi, dimana RRL salah dalam menuliskan perbandingan sehingga menghasilkan jawaban yang salah. Sedangkan subjek RRP kurang mampu melaksanakan rencana karena RRP salah menuliskan perbandingan uang hani sehingga menghasilkan perhitungan yang salah.

d. Memeriksa kembali

Subjek RRL dan RRP belum mampu melakukan tahap ini, karena kedua subjek tidak memereriksa kembali jawabannya.

$\begin{array}{llll}\mathrm{R} & : \text { Kenapa gaditulis diketahui nya? } & \mathrm{R} & : \text { Kamu paham soalnya ga? } \\ \mathrm{RRL} & : \text { lupa bu } & \mathrm{RRP} & : \text { Lumayan paham }\end{array}$ 


\begin{tabular}{|c|c|c|c|c|c|}
\hline $\mathrm{R}$ & : & $\begin{array}{l}\text { Informasi apa saja yang diketahui } \\
\text { dari soal tersebut? }\end{array}$ & $\mathrm{R}$ & & Coba apa yang diketahui dari soal tersebut? \\
\hline RRL & : & $\begin{array}{l}\text { Hani dan Resti itu 5:4, sedangkan } \\
\text { Resti dan Tantri itu 3:4. Terus jumlah } \\
\text { uang mereka itu Rp43.000,00, }\end{array}$ & RRP & . & $\begin{array}{l}\text { Uang hani dan resti }=5: 4 \\
\text { Uang resti dan tantri }=3: 4\end{array}$ \\
\hline $\mathrm{R}$ & : & Lalu apa yang ditanya? & $\mathrm{R}$ & & Lalu apa yang ditanya? \\
\hline RRL & : & tentukan besar uang Hani adalah & RRP & • & Uang Hani \\
\hline $\mathrm{R}$ & $:$ & kamu periksa lagi ga jawaban kamu? & $\mathrm{R}$ & & Kamu periksa lagi ga jawabannya? \\
\hline RRL & : & Engga diperiksa lagi & RRP & & iya ka saya liat lagi jawabannya \\
\hline $\mathrm{R}$ & $:$ & apa kesimpulan dari jawaban kamu? & $\mathrm{R}$ & & emang perbandingan hani $12 ?$ \\
\hline \multirow[t]{2}{*}{ RRL } & $:$ & maka uang hani adalah Rp20.000 & RRP & & $\begin{array}{l}\text { Ehiya ka } 15 \text { salah liat berarti uang hani } \\
\text { Rp15.000 ka }\end{array}$ \\
\hline & & & $\begin{array}{l}\mathrm{R} \\
\mathrm{RRP}\end{array}$ & $\sigma^{\circ}$ & $\begin{array}{l}\text { Kan udah diperiksa ko masih salah? } \\
\text { iya ka saya kurang teliti }\end{array}$ \\
\hline
\end{tabular}

Tabel berikut merupakan hasil analisis kemampuan pemecahan masalah matematis yang diperkuat dengan data wawancara.

Tabel 1. Ringkasan Analisis Proses Pemecahan Masalah Matematis dengan Kategori Resiliensi Tinggi

\begin{tabular}{|c|l|l|}
\hline \multirow{2}{*}{ Indikator } & \multicolumn{2}{|c|}{ Resiliensi tinggi } \\
\cline { 2 - 4 } & \multicolumn{1}{|c|}{ RTL } & \multicolumn{1}{|c|}{ RTP } \\
\hline \multirow{3}{*}{1} & $\begin{array}{l}\text { Subjek RTL tidak menuliskan yang diketahui } \\
\text { pada soal dan tidak menulis yang ditanyakan., } \\
\text { namun berdasarkan bukti hasil wawancara dan } \\
\text { dilihat dari proses penyelesaian masalah RTL } \\
\text { dapat memahami masalah. }\end{array}$ & $\begin{array}{l}\text { RTP sudah mampu memenuhi indikator } \\
\text { dengan menuliskan yang ditanyakan dan } \\
\text { menuliskan informasi yang diketahui } \\
\text { seperti perbandingan uang, harga jual, } \\
\text { harga beli, cicilan, dan DP. }\end{array}$ \\
\hline \multirow{2}{*}{2} & $\begin{array}{l}\text { Subjek RTL mampu membuat rencana } \\
\text { dengan menggunakan informasi yang ada } \\
\text { untuk menentukan strategi namun RTL tidak } \\
\text { menuliskan rumus. }\end{array}$ & $\begin{array}{l}\text { RTP mampu membuat rencana dengan } \\
\text { menggunakan informasi yang ada untuk } \\
\text { merencanakan strategi dan mampu } \\
\text { menuliskan rumus pada nomor 4 dan 8. }\end{array}$ \\
\hline \multirow{2}{*}{3} & $\begin{array}{l}\text { Subjek RTL dapat melaksanakan rencana } \\
\text { dengan melakukan proses penyelesaian } \\
\text { masalah secara sistematis. Namun subjek } \\
\text { RTL salah perhitungan di soal nomor 4 dan 6 } \\
\text { sehingga menghasilkan jawaban yang salah. }\end{array}$ & $\begin{array}{l}\text { Subjek RTP dapat melaksanakan rencana } \\
\text { dengan melakukan proses penyelesaian } \\
\text { masalah secara sistematis dan RTP mampu } \\
\text { melakukan perhitungan dengan baik hanya } \\
\text { saja subjek keliru pada soal nomor 6. }\end{array}$ \\
\hline
\end{tabular}




\begin{tabular}{|l|l|l|}
\hline 4 & $\begin{array}{l}\text { RTL memereriksa kembali jawabannya } \\
\text { dengan melakukan pemeriksaan pada proses } \\
\text { perhitungannya }\end{array}$ & $\begin{array}{l}\text { Subjek RTP melakukan peeriksaan kembali } \\
\text { dengan menghitung ulang jawabannya. }\end{array}$ \\
\hline
\end{tabular}

Tabel 2. Ringkasan Analisis Proses Pemecahan Masalah Matematis dengan Kategori Resiliensi Sedang

\begin{tabular}{|c|c|c|}
\hline \multirow{2}{*}{ Indikator } & \multicolumn{2}{|c|}{ Resiliensi sedang } \\
\hline & RSL & $\overline{R S P}$ \\
\hline 1. & $\begin{array}{l}\text { Subjek tidak menuliskan yang diketahui } \\
\text { dan tidak menulis yang ditanyakan, namun } \\
\text { berdasarkan hasil wawancara dan dilihat } \\
\text { dari proses penyelesaian masalah RSL } \\
\text { dapat memahami masalah. }\end{array}$ & $\begin{array}{l}\text { Subjek tidak menuliskan yang diketahui } \\
\text { dan tidak menulis yang ditanyakan, } \\
\text { namun berdasarkan hasil wawancara } \\
\text { dan dilihat dari proses penyelesaian } \\
\text { masalah RSL dapat memahami } \\
\text { masalah. }\end{array}$ \\
\hline 2. & $\begin{array}{l}\text { Subjek RSL mampu membuat rencana } \\
\text { dengan menggunakan informasi yang ada } \\
\text { untuk menentukan strategi namun RSL } \\
\text { tidak menuliskan rumus untuk } \\
\text { menyelesaikan masalah pada beberapa soal } \\
\text { namun RSL tidak menuliskan rumus pada } \\
\text { jawaban nomor } 4 \text { dan } 8 \text {. RSL keliru dalam } \\
\text { membuat rencana pada soal nomor } 6 \text { dan } 7 .\end{array}$ & $\begin{array}{l}\text { Subjek RSP mampu membuat rencana } \\
\text { dengan menggunakan informasi yang } \\
\text { ada untuk menentukan strategi, namun } \\
\text { RSP kurang mampu membuat rencana } \\
\text { pada soal nomor } 3,6,7 \text {, dan } 8 \text {. RSP } \\
\text { tidak menjawab soal nomor } 7 \text {. }\end{array}$ \\
\hline 3. & $\begin{array}{l}\text { Subjek RSL dapat melaksanakan rencana } \\
\text { dengan melakukan proses penyelesaian } \\
\text { masalah secara sistematis meskipun RSL } \\
\text { mengalami kebingungan saat proses } \\
\text { perhitungan pada soal nomor } 5,6 \text {, dan } 7 \\
\text { sehingga menghasilkan jawaban yang } \\
\text { salah. }\end{array}$ & $\begin{array}{l}\text { Subjek RSP dapat melaksanakan } \\
\text { rencana dengan melakukan proses } \\
\text { penyelesaian masalah secara sistematis } \\
\text { pada beberapa soal, namun subjek RSP } \\
\text { salah melaksanakan rencana pada soal } \\
\text { nomor 3, 6, 7, dan } 8 \text {. }\end{array}$ \\
\hline 4. & $\begin{array}{l}\text { RSL memereriksa kembali jawabannya } \\
\text { dengan dihitung kembali. }\end{array}$ & $\begin{array}{l}\text { Subjek RSP cenderung tidak memeriksa } \\
\text { kembali proses perhitungannya. }\end{array}$ \\
\hline
\end{tabular}


Tabel 3. Ringkasan Analisis Proses Pemecahan Masalah Matematis dengan Kategori Resiliensi Rendah

\begin{tabular}{|c|c|c|}
\hline \multirow{2}{*}{ Indicator } & \multicolumn{2}{|c|}{ Resiliensi rendah } \\
\hline & RRL & RRP \\
\hline 1. & $\begin{array}{l}\text { Subjek RRL tidak menuliskan yang } \\
\text { diketahui dan tidak menulis yang } \\
\text { ditanyakan, berdasarkan wawancara RRL } \\
\text { tidak menyebutkan yang diketahui dengan } \\
\text { lengkap tetapi RRL bisa menjawab soal } \\
\text { nomor 2,6,7 artinya RRL belum } \\
\text { memahami masalah. }\end{array}$ & $\begin{array}{l}\text { RRP sudah mampu memahami masalah } \\
\text { nomor 5,6,8. Selain nomor tersebut } \\
\text { RRP hanya menuliskan yang } \\
\text { ditanyakan dan menuliskan informasi } \\
\text { yang diketahui secara tidak lengkap. } \\
\text { RRP keliru pada nomor } 4 \text {. }\end{array}$ \\
\hline 2. & $\begin{array}{l}\text { RRL belum mampu membuat rencana } \\
\text { dengan menggunakan informasi yang ada } \\
\text { untuk menentukan strategi pada nomor } \\
\text { 3,4,5,7 8. RRL hanya mampu membuat } \\
\text { rencana pada nomor } 2 \text {, dan } 6 \text {. }\end{array}$ & $\begin{array}{l}\text { RRP belum mampu membuat rencana } \\
\text { dengan menggunakan informasi yang } \\
\text { ada untuk menentukan strategi pada } \\
\text { nomor nomor } 2,3,4,6 \text {, dan } 7 \text {. } \\
\text { RRP hanya mampu menjawab soal } \\
\text { nomor } 5,6 \text {, dan } 8 \text {. }\end{array}$ \\
\hline 3. & $\begin{array}{l}\text { Karena subjek RRL belum mampu } \\
\text { membuat rencana sehingga RRL tidak } \\
\text { dapat melaksanakan rencana. Dimana } \\
\text { RRL hanya dapat menjawab soal nomor 1, } \\
2,6 \text {, dan } 8 \text { dengan menyertakan proses } \\
\text { penyelesaian masalah dan sisanya hanya } \\
\text { menuliskan jawaban yang salah tanpa ada } \\
\text { proses penyelesaian. }\end{array}$ & $\begin{array}{l}\text { Karena subjek RRP belum mampu } \\
\text { membuat rencana sehingga RRP belum } \\
\text { mampu melaksanakan rencananya. } \\
\text { Dimana RRP menjawab soal nomor } 8 \\
\text { dengan benardan tidak mencoba } \\
\text { menjawab untuk soal } 2,3 \text {, dan } 7 \text {. Soal } \\
4,5 \text {, dan } 6 \text { RRP salah dalam proses } \\
\text { menghitung. }\end{array}$ \\
\hline 4. & $\begin{array}{l}\text { Subjek RRL tidak memeriksa kembali } \\
\text { pada proses penyelesaian maupun proses } \\
\text { perhitungan. }\end{array}$ & $\begin{array}{l}\text { Subjek RRP cenderung tidak } \\
\text { memeriksa kembali proses penyelesaian } \\
\text { maupun proses perhitungannya. }\end{array}$ \\
\hline
\end{tabular}

Berdasarkan paparan dari ketiga tabel terlihat bahwa kedua subjek resiliensi tinggi mampu memenuhi 4 indikator Polya, sedangkan subjek yang termasuk kategori resiliensi sedang kurang mampu melaksanakan rencana karena subjek keliru saat proses perhitungan. Hal ini diperkuat dengan hasil penelitian sebelumnya yang menunjukkan bahwa peserta didik dengan resiliensi matematis tinggi memiliki kemampuan pemecahan masalah matematis yang baik, sedangkan peserta didik yang termasuk resiliensi sedang dan rendah kurang mampu dalam pemecahan masalah matematis (Attami et al., 2020; Rahmatiya \& Miatun, 2020). Untuk subjek yang termasuk kategori resiliensi rendah kurang mampu memenuhi 4 indikator 
pemecahan masalah menurut Polya dan mudah menyerah saat menghadapi permasalahan yang tidak dimengerti.

\section{KESIMPULAN}

Menurut hasil analisis data subjek yang termasuk kategori resiliensi tinggi sudah mampu memenuhi empat indikator pemecahan masalah menurut Polya, dimana perempuan dan laki-laki mampu memenuhi indikator 1 dan 4, sedangkan perempuan lebih baik dari laki-laki pada indikator 2 dan 3, sedangkan subjek yang termasuk dalam kategori resiliensi sedang dimana laki-laki lebih baik dari perempuan pada keempat indikator. Hanya saja subjek katgeori resiliensi sedang kurang teliti dalam menghitung sehingga menghasilkan jawaban yang salah. Subjek dengan resiliensi sedang tidak mudah menyerah saat mengalami kesulitan. Untuk subjek kategori resiliensi rendah kedua subjek belum mampu memenuhi keempat indikator namun perempuan lebih baik dari laki-laki. Subjek resiliensi rendah lebih mudah menyerah saat mengalami kesulitan.

\section{REFERENSI}

Attami, D., Budiyono, B., \& Indriati, D. (2020). The mathematical problem-solving ability of junior high school students based on their mathematical resilience. Journal of Physics: Conference Series, 1469(1). https://doi.org/10.1088/1742-6596/1469/1/012152

Buranda, M. S., \& Bernard, M. (2019). Analisis Kemampuan Pemecahan Masalah Matematik Materi Lingkaran Siswa Smp Berdasarkan Gender. JPMI (Jurnal Pembelajaran Matematika Inovatif), 2(1), 33. https://doi.org/10.22460/jpmi.v2i1.p33-40

Davita, P. W. C., \& Pujiastuti, H. (2020). Anallisis Kemampuan Pemecahan Masalah Matematika Ditinjau Dari Gender. Kreano, Jurnal Matematika Kreatif-Inovatif, 11(1), 110-117. https://doi.org/10.15294/kreano.v11i1.23601

Hafiz, M., Darhim, \& Dahlan, J. A. (2017). Comparison of Mathematical Resilience among Students with Problem Based Learning and Guided Discovery Learning Model. Journal of Physics: Conference Series, 895(1). https://doi.org/10.1088/1742-6596/895/1/012098

Hutauruk, A. J. B., \& Priatna, N. (2017). Mathematical Resilience of Mathematics Education Students. Journal of Physics: Conference Series, 895(1). https://doi.org/10.1088/1742-6596/895/1/012067

Ince, E. (2018). An Overview of Problem Solving Studies in Physics Education. Journal of Education and Learning, 7(4), 191. https://doi.org/10.5539/jel.v7n4p191

Kooken, J., Welsh, M. E., McCoach, D. B., Johnston-Wilder, S., \& Lee, C. (2016). Development and validation of the mathematical resilience scale. Measurement and Evaluation in Counseling and Development, 49(3), 217-242.

Megan, E., Betsy, D., \& Lee, S. (2013). warwick.ac.uk/lib-publications. 2013(2012).

OECD. (2019). PISA 2018 Results. Combined Executive Summaries. Journal of Chemical Information and Modeling, 53(9), 1689-1699. 
Polya, G. (1985). Polya_HowToSolvelt.pdf.

Rahmatiya, R., \& Miatun, A. (2020). Analisis kemampuan pemecahan masalah matematis ditinjau dari resiliensi matematis siswa SMP. Teorema: Teori Dan Riset Matematika, 5(2), 187-202.

Rijali, A. (2019). Analisis Data Kualitatif. Alhadharah: Jurnal Ilmu Dakwah, 17(33), 81. https://doi.org/10.18592/alhadharah.v17i33.2374

UNDANG-UNDANG REPUBLIK INDONESIA NOMOR 20 TAHUN 2003 TENTANG SISTEM PENDIDIKAN NASIONAL. (2006).

Winarso, W. (2017). Pengaruh Perbedaan Tipe Kepribadian Terhadap Sikap Belajar Matematika Siswa Sma Islam Al-Azhar 5 Cirebon. Jurnal Pendidikan Matematika, 2(1), 94. https://doi.org/10.18592/jpm.v2i1.1170. 